\title{
Ephrin Type-B Receptor 1
}

National Cancer Institute

\section{Source}

National Cancer Institute. Ephrin Type-B Receptor 1. NCI Thesaurus. Code C26162.

Ephrin type-B receptor 1 (984 aa, $110 \mathrm{kDa}$ ) is encoded by the human EPHB1 gene. This protein plays a role in both ephrin-B binding and tyrosine phosphorylation. 